\title{
"A theoretical exposition of State Capture as a means of state formation: The case of South Africa"
}

\begin{tabular}{|c|c|}
\hline AUTHORS & Petrus Croucamp iD https://orcid.org/0000-0001-5341-0618 \\
\hline ARTICLE INFO & $\begin{array}{l}\text { Petrus Croucamp (2019). A theoretical exposition of State Capture as a means of } \\
\text { state formation: The case of South Africa. Problems and Perspectives in } \\
\text { Management, 17(4), 289-298. doi:10.21511/ppm.17(4).2019.24 }\end{array}$ \\
\hline DOI & http://dx.doi.org/10.21511/ppm.17(4).2019.24 \\
\hline RELEASED ON & Monday, 23 December 2019 \\
\hline RECEIVED ON & Monday, 15 April 2019 \\
\hline \multirow[t]{2}{*}{ ACCEPTED ON } & Wednesday, 13 November 2019 \\
\hline & $(\mathrm{cc}) \mathbf{E Y}$ \\
\hline LICENSE & $\begin{array}{l}\text { This work is licensed under a Creative Commons Attribution } 4.0 \text { International } \\
\text { License }\end{array}$ \\
\hline JOURNAL & "Problems and Perspectives in Management" \\
\hline ISSN PRINT & $1727-7051$ \\
\hline ISSN ONLINE & $1810-5467$ \\
\hline PUBLISHER & LLC "Consulting Publishing Company "Business Perspectives" \\
\hline FOUNDER & LLC "Consulting Publishing Company "Business Perspectives" \\
\hline & 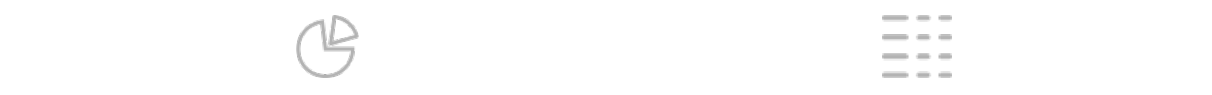 \\
\hline NUMBER OF REFERENCES & NUMBER OF FIGURES \\
\hline 26 & $\mathbf{0}$ \\
\hline
\end{tabular}

(c) The author(s) 2022. This publication is an open access article. 


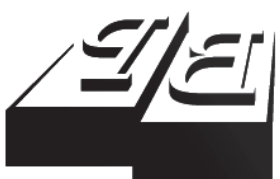

BUSINESS PERSPECTIVES

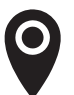

LLC "CPC "Business Perspectives" Hryhorii Skovoroda lane, 10, Sumy, 40022, Ukraine

www.businessperspectives.org

Received on: $15^{\text {th }}$ of April, 2019 Accepted on: $13^{\text {th }}$ of November, 2019

(C) Petrus Croucamp, 2019

Petrus Croucamp, Ph.D., Senior Lecturer, Department of Politics and Government Studies, North West University, Vanderbijlpark, South Africa.

\section{A THEORETICAL EXPOSITION OF STATE CAPTURE AS A MEANS OF STATE FORMATION: THE CASE OF SOUTH AFRICA}

\begin{abstract}
This theoretical exposition aims to add to existing theory on state design and the durability of the liberal democratic experiment. This paper is written on the case of South Africa and the rise of contending regime narratives on the interaction between the state and the economy. The notion of the state being 'captured' may well be a nomenclature typical of a great number of states in developing political economies. While the scholarly analysis of weak or fragile states is, to a significant extent, embedded in South African political theory, the notion of a captured state is often conflated with the conceptual confines of the corrupt or criminalized state. The research result - or theoretical contribution this article makes - is to substantiate the postulation that state capture as a feature of state formation also reflects the emergence of a contending or alternative regime preference with a distinct moral justification supplementing liberal democratic experiments. Experimental liberal democracies are more prone to such constitutional or regime challenges. While systemic patronage is a regime preference, which often co-exists with liberal regime imperatives within the constitutional domain of liberal regimes, this paper reviews the state capture as the manifestation of sectarian interests in the formal economy encroaching on the domain of the constitutional state to gain a competitive advantage within the market/economy.
\end{abstract}

Keywords theory, regime, liberalism, clientelism, patrimonialism

JEL Classification

B4, B5

\section{INTRODUCTION}

The role of the state is to serve the collective interests of society. To that end, the various institutions and managers of the state are constitutionally empowered to extract the necessary resources from the economy - responsibly and prudently - and to distribute such resources in a fair and equitable manner. The state and society are bound together through a complexity of institutionalized arrangements (a social contract), and the constitutional realm of the state is clearly delineated to allow for a distinctive operational space (interface) between the respective interests of the state, society, and the economy.

In liberal democratic political economies, the state is discouraged, if not statutorily prevented, from encroaching on the spatial realm of society and the institutional architecture of the state functions independently from (encroaching) sectarian interests prevalent throughout society.

The institutionalization of social order is primarily the function of the state, and the constitution dictates the architecture of such order. Social order, however, is also the result of varying and contending regime preferences operative on the interface between state and society, 
but which were conceived in uncodified social and political relations. Systemic patronage, patrimonialism, and state capture are regime preferences competing with liberal-democratic forms of institutionalization, but any number of regime preferences may exist in a single political economy, stabilizing the contending interests and legitimizing the authority of the state. This article aims to revisit the existing theories of social order and contribute analytically by advancing new dimensions of theoretical (comparative) analysis. The exposition is largely theoretical, but the reference is also made to South Africa, as well as case studies in Southern Africa.

\section{THEORETICAL BASIS}

Systemic patronage as a regime preference reflects an (informal, as well as formal) anatomy of social order, which calibrates the consequences of political power with the requirements of institutional legitimacy. It is also a system, which legitimizes a 'moral economy' of (re)distributive practices in highly unequal political economies (Adams, 2009, p. 66). The descriptive nomenclature of systemic patronage is empowerment, affirmative action, and cadre deployment. Economic inequality is defined in terms of its political dimensions, but also as a social construct between the past and the present. These concepts are operationalized to serve a policy agenda, which is aimed at addressing inequality, but also at empowering the ruling elite (Darracq, 2008 , p. 44). Bureaucrats, thus, are largely cadres empowered by their historical or recent association with the liberationist regime who seek to legitimize a narrative of redress by distributing the revenue and resources of the state to advance the interests of a particular regime preference.

A second prevailing regime preference is manifested in the idiom of the captured state (Hellman, Jones, Kaufmann, \& Schankerman, 2000, p. 55). The captured state is defined by the codification of informal relations between politically powerful bureaucrats (cadres) and economic actors within the formal economy. Such actors typically seek to establish or consolidate the monopolies vis-à-vis their natural contenders within the private sector of the economy. The captive state is (institutionally) weakened by the erosion of its constitutional authority, but the mandate of the state - vis-à-vis civil society - is conditioned by the securitization of social and political relations, which strengthen the interventionist capacities of the political elite.

A third regime preference, which determines social, political and economic relations, is a so- cial hierarchy in which the mandate to govern is embedded in the personal authority of elites. Patrimonialism is a system of authority and governance associated with authoritarian regimes, but which exists comfortably together with other regime preferences in the realm of weak and captured states (Lodge, 2014, p. 22; Hellman, Jones, Kaufmann, \& Schankerman, 2000, p. 58; Pitcher, Moran, \& Johnston, 2009, pp. 33-55).

The three regime preferences above often co-exist together in a single political economy, and the dominance of a particular preference in the policy and governance domain is determined by the extractive and distributive capacities of the state (Migdal, 1988, p. 69). The state has a constitutional obligation to regulate and/or intervene in the normal functioning of the economy. It extracts the resources from the economy required to maintain its obligations towards society and it distributes such resources in a just and equitable manner.

Preferential access to the authority of the state or the distributive regime of the state is often perceived as an indispensable legislative or constitutional imperative, needed to address historical injustices or to expedite the eradication of social and economic inequality. It is therefore a prerequisite for political legitimacy and social stability, especially so under conditions of a negotiated regime change. Preferential access in a utilitarian sense is conceived in the logic of a meritocratic hierarchy, which ranks the inefficiency low and rewards the varying attributes of institutional efficiency. In the liberationist reasoning, the hierarchy of redress and social justice determine the outcome of access, and merit is secondary to social, economic and political redress (Grzymala-Busse, 2008, p. 3).

The relational tissue of preferential access binds bureaucrats in all spheres of the state to social and economic aggregates within the society. With 
the developing state often being at its weakest in the local sphere, the operational attributes of the relational tissue between local government and economic interests tend to vary significantly between being efficient and being corrupt. 'Weakest' implies that the (local) state lacks the institutional autonomy to resist the opportunistic interests of social and economic interests encroaching on the regime perimeters of the state (Hellman, Jones, Kaufmann, \& Schankerman, 2000, p. 57; Mbeki, 2005 , p. 55). In political systems where the point of the merger between the state and the (ruling) party is ambiguous, party-political interests and the responsibility of governance to serve the greater good often conflate at the expense of the latter.

Cadres are ideologically devoted members of the governing party. As Lodge suggests (2014, p. 12), they are deployed within the state or related state institutions to embed the legitimacy of the party or party policies. In terms of the liberationist narrative, cadres are not necessarily obliged to serve the universal interest; they bond the state to selected constituencies in the patronage of a normative ideological assumption of justice and social order. Interests beyond the ideological assumption of 'redress' are juxtaposed as outsiders to the norm of justice, and society is deliberately fragmented to consolidate the solidarity within a 'preferred constituency'.

As regards electoral contestation, the aim is not to attract voters from outside to the preferred support base, but rather to mobilize the involvement and participation of those who are historical and ideological associates of the liberationist narrative (Quimpo, 2005, p. 42). Cadres or the political functionaries of the executive reinforce loyalty to the liberationist narrative through a distributive regime of preferential access and by emphasizing the benefits of governance as a zero-sum contest between insiders and outsiders (Hellman, Jones, Kaufmann, \& Schankerman, 2000, p. 60). In a constitutional democracy, opposition constituents - or outsiders - rely on the 'cost and consequences of alienation' to pressurize the political elite (cadres or members of the executives) into compromises. Part of the reason for their outsider status is the perceived operational - or even moral - distance between the narratives of liberationism and liberalism.
Liberalism has a checkered history as a means of securing electoral support for African political elites (Bogaards, 2004, p. 183). No political party with an overtly liberal agenda has ever won a national election in Africa. In South Africa, the liberal Democratic Alliance (DA) relies heavily on the loyalty of the largely white constituencies to govern a number of municipalities and metropoles in alliance with smaller parties. In the province of the Western Cape, where the African vote is approximately $25 \%$ of the eligible voters, the DA has secured $60 \%$ of the support of the colored and white voters.

The question is what would be the connective tissue between the African political and bureaucratic elite and electoral support (Erdmann \& Engel, 2007 , p. 102). In liberal democratic regimes, it could be assumed that the legitimacy of institutions or the political elite to govern is derived from the utilitarian necessity to represent varying, contending or collective societal interests. The political elite commits themselves to a definitive regime preference which broadly mirrors the interests and socio-political values of identified constituencies (Hellman, Jones, Kaufmann, \& Schankerman, 2000 , p. 333). In a constituency-based electoral system, the relationship between political elites and societal interests could be rather personal. In proportional or list (electoral) systems, the operation remoteness between constituencies and representatives allows less direct accountability but also introduces the notion of trust as connective tissue between elites and representatives. As Beresford (2009, p. 31) suggests, in constituency-based systems, accountability precedes trust, but in proportional or list systems, trust precedes accountability. The measure of accountability has the individual as the unit of analysis, while trust is measured as a (systemic) responsiveness to the collective or the greater good.

Liberationist regimes, largely due to the normative assumption of its raison d'etre, are highly reliant on trust and significantly less so on accountability (Subudubudu \& Molutsi, 2009, p. 44). Accountability may well be a destabilizing or unstable variable undermining or corroding (institutional) legitimacy in liberationist regimes as it challenges the moral and/or historical justifications of an almost deific political authority. In 
liberationist regimes, the representative (accountability) is replaced by the cadre (trust), the latter encapsulating a 'moral authority' of 'insiders'.

In liberal systems, a principle of meritocracy is assumed - if not applied - as a means of social and economic mobility. The suggestion could be that in this context accountability is driven through systemic efficiency with emphasis on the individual as the unit of analysis (Young, 1958, p. 44). Mobility within the system is operationalized in performance, skills and adaptability and the probability that these individual skills with benefit the system or the greater good. The greater good comes about as a consequence of individual ingenuity.

As for elites in liberationist regimes, empowerment is the primary driving force of economic and or political mobility. The moral justifications for empowerment are historical, undeniable and incontrovertible. As an economic agenda, it addresses the demographic inequalities, which are conceived in historical injustices, and as a political practice, it legitimizes political management and institutional governance. Empowerment is a means of replicating the authority of political elites in the institutional architecture of economy and the relational fabric of civil society. Cadre deployment from the governing party to sources of authority within the state, economy and even society becomes a fundamental feature of broadening the principles of trust. In practice, it means political elites within the liberationist regime gain access to the extractive, as well as the distributive institutions of social, financial and economic control. Their empowerment entrenches political trust at the expense of accountability. In liberationist regimes, accountability is sectarian - often to the party - and not to the state or the 'greater good'.

The phenomenon of state capture is often reflected upon in the popular nomenclature of corruption. In a more scholarly realm, it could be postulated that state capture is the consequence or result of opportunistic social relations, which allows individuals or companies in the formal economic sphere to enrich themselves - or their (economic) interests - by extracting undue resources from a state department/institution or a state-owned enterprise (SOE), which provides such interests with a competitive advantage vis-à-vis other economic interest in a market environment. The feature of state capture, which distinguishes it from corruption, systemic patronage or neo-patrimonial relations is the fact that it occurs under conditions of an open political system and the prevalence of a market economy.

The dominant economic actors do not become part of the state or occupy any position of authority within the state. In fact, such actors most likely have no historical membership of - or association - with the liberation regime. They are primarily functionaries within the market economy seeking to establish social relations with cadres within operational reach of the state's distributive or policy regime through which the flow of goods and services is then managed to allow for (their) privileged, but undue access.

Lodge (2014, p. 26), however, suggests that such "opportunistic relations" are historical and reminiscent of the social capital, which defined the operative dynamics of liberations struggles. The African National Congress (ANC) is, thus, no exception to the pattern and phenomenon of opportunistic relations between the owners of capital and strongmen in the struggle. Lodge furthermore operationalizes the "captured state" - phenomenon as 'conceived in the types of pressures emanating from electoral politics (a feature predominant to liberal democratic systems).' The ANC's "historical ties to criminal networks and pressures arising from the transition to majority rule and contemporary electoral politics" thus provides for the embeddedness of personalized authority (neo-patrimonial regimes) (Lodge, 2014, p. 27; Subudubudu \& Molutsi, 2009, p. 44). The state and its institutions then serve the opportunistic or corrupt interests of individuals, families or social aggregates, as opposed to the interests of the greater good.

While the idea of a captured state might have left a (historical) sediment in scholarly theories of state-societal relations in developing or post-conflict political economies experimenting with liberal systems, more recent research tends to equate the regime preference of state capture with corruption (see Hellman, Jones, Kaufmann, \& Schankerman, 2000, p. 55; Grzymala-Busse, 2008, p. 39). Matekga (2016), Basson and du Toit (2017), 
and Pauw (2017) are investigative (South African) journalists who wrote extensively about not only the "captured presidency" of Jacob Zuma, but also the extent to which state departments and were trapped in the tentacles of political control beyond the constitutional realm. Similar to the popular parlance, state capture has been defined political and economic corruption. But, theoretically state capture is predominantly a means of social order and control. It, therefore, makes sense to analyze state capture a regime preference with an institutional architecture and political durability, which also prevails on the interface between state and society.

The captive state is a weak state with its constitutional authority dispersed to destructive aggregates within society (Grzymala-Busse, 2008, p. 659). The connective bind between state and society is the cadre who is operative as either a bureaucrat or a political functionary within the state or related institutions. Cadres serve as a conduit between societal interests and executive authority in any of the three spheres of the state (Pauw, 2017, pp. 23-88). Such an institutional anatomy evolves as a consequence of what is known as the 'urges towards state capture,' which emanates from preferential access, but which is also due to the proliferation of patron-client relations or corrupt economic or financial arrangements between cadres and/or bureaucrats within the civil service or state-owned organizations (SOEs). State capture as a process is related to the institutional edifice of corruption, but corruption is not necessarily due to the prevalence of state capture (Hellman, Jones, Kaufmann, \& Schankerman, 2000, p. 55). These are theoretically distinct institutional arrangements and it may overlap or be functional as an autonomous feature of state-societal relations.

The concept of state capture was conceived in the South African news media and academia has not yet cultivated significant or sufficient consensus as regards either the conceptual range or the operational attributes thereof. If state capture is defined as an act whereby the state is occupied by opportunistic interests, the question which remains is: why is it that the dominant actors in the process rarely if ever occupy formal positions within the state. For instance, the Guptas never occupied any position within the state. Their activities were largely relational and the individuals with whom they 'colluded' were by and large members of the ruling party employed within the jurisdiction of the state - or 'deployed' by the governing party to 'occupy' positions within SOEs where policy would be implemented to realize the legitimate policy positions of the governing party (Pauw, 2017, pp. 23-206).

The operational distinction between relations within the captured state and those "legal bureaucratic" (Erdmann \& Engel, 2007, p. 105) arrangements of systemic patronage is that the (opportunistic) economic actors in the private economy, enters the equation from the outside - in this case outside implies from beyond the liberationist paradigm - while even the corrupt patrons are operative from within the moral economy of systemic patronage. The legitimacy of the claims to preferential access made by opportunistic economic actors - to being 'insiders' - is contested by both the systemic clientele and the natural contenders of the agents of state capturing within the private sphere of the economy.

Erdmann and Engel (2007, p. 161) and Lodge (2014) seem to be in agreement that the South African political economy harbors two contending, co-existing or even merged regimes of social control: "a mixture of two co-existing, partly interwoven, types of domination: namely patrimonial and legal bureaucratic domination." The authors appreciate the inevitability of a market-driven (policy) regime. However, they make no distinction between patrimonialism and the different architecture of state capture, which encroached onto the post-apartheid regime. Lodge (2014, p. 77) postulates that: "In Africa, neo-patrimonial politics is often a residue of authoritarian politics, both colonial and post-colonial, with the result that many of today's ostensible democracies are in fact transitional hybrids, 'neo-patrimonial multi-party systems.' Generally, such an assumption is all too often true in the context of politics in the developing political economies of Africa, but the South African experiment with liberal democratic regime-theory can hardly be described as "authoritarian” (Pitcher, 2009; Moran \& Johnston, 2009).

Lodge (2014, p. 77) explains the manifestation of patrimonialism in South Africa as: "Neo- 
patrimonial indicators include the acquisition of business interests by leading politicians and their families, most notably the proliferation of the presidential family's business concerns since Jacob Zuma's accession to the presidency." It seems the added dimension to the equation for Lodge is the extension of the president's family interests into the formal (or informal) economy.

\section{RESULTS}

In terms of an index by Transparency International (2017), South Africa is ranked 71/180 with a score of 43/100 in terms of corruption. Zero would be a measure of a completely corrupt public service and 100 would be an indication of no corruption at all. Sub-Saharan Africa is one of the worst-performing regions with an average score of 32 , and two-thirds of the world's countries are below 50 with an average of 43 . Whereas preferential access to the scarce resources through empowerment augments the legitimacy of the government and the state, albeit, amongst selected constituencies, corruption undermines the trust between state and society and, subsequently, it also corrodes the legitimacy of state institutions.

Cadre deployment is a means by which the governing party entrenches its regime preferences. In the context of a post-colonial history or a post-apartheid history, it legitimizes the state, the constitutional regime and the rules of (conflict) mediation (Hellman, Jones, Kaufmann, \& Schankerman, 2000, p. 55). Cadre deployment should be distinguished from black economic empowerment and affirmative action policies. The deployment committee of the governing party is tasked with the deployment and redeployment of cadres with the intention to 'involve' the liberation movement in the process of governance and to provide opportunities for active members of the governing party to become part of the management of the political and economic process. Cadres can be deployed within the bureaucracy, state-owned institutions (SOI), legislatures or within the structures of the governing party.

The required normative politico-psychology is loyalty to the party as opposed to the state of the constitution. Cadres serve as a conduit between party and state and it merges the interests of the state with that of the party (Mbeki, 2005, p. 126). Cadres oblige the interests of the governing party within the state. Cadres are often also 'employed' by 'captains of industry' in the 'white economy' in an effort to gain preferential access to the distributive regime of the state or to be excluded from the redistributive policies. Redistributive policies often have rewards for compliance. If and when cadres themselves gain preferential or opportunistic access to the distributive regime of the state with the aim at personal enrichment, it is called corruption (Hellman, Jones, Kaufmann, \& Schankerman, 2000, p. 55). However, when they provide entrepreneurs in the private economy access to the decision making structures or the institutions of policy execution, they allow the process and procedure of governance to be unduly influenced and captured by economic interests beyond the realm of governance.

Many functionaries fundamental to the administration of extraction, distribution and management at the local sphere of the state are appointed as cadres with the responsibility to comply with party-political discipline as opposed to serving the universal interests of civil society. However, by and large, civil servants fulfill responsibilities, which grant them insufficient authority to disturb the bureaucratic obligations of their functionality. They are far removed from the dynamics of state capture and might never or rarely be in a position to either circumvent the statutory rigidities of the financial management act or to influence departmental policies. As implied by Hellman, Jones, Kaufmann, and Schankerman (2000, p. 55), whatever function these bureaucrats may fulfill, their behavior is shaped by the weaknesses and strengths of the institutional culture, particular of the sphere of the state where they implement policy. The do not design policy, and they do not design corruption or state capture. The system has to be weak and ineffective or lack managerial oversight for them to behave in a corrupt manner.

Systemic corruption and preferential access to the state's distributive regime (systemic patronage) are functional at the managerial level of the state where cadres are typically employed or deployed to embed the regime preferences of the governing party. If the governing party becomes permeat- 
ed by dispersed authorities beyond the control of the (party) political elite, the regime preferences, which determine the distributive interests of the state challenges the rules, regulations, and values of good governance. It is improbable that a weak, fragmented, corrupt, and captured state is occupied by a less corrupt governing party.

The notion of the 'captured state' as an institutionalized form of social order in (experimental) liberal democratic regimes has largely entered the analytical domain of political theory through the case study of South Africa. The concept is used by among others Grzymala-Busse (2008) and Hellman, Jones, Kaufmann, and Schankerman (2000), but the operationalization of the phenomenon was large done through the non-scholarly research of journalists such as Mathekga (2016) and Pauw (2017).

Much of the captured state narrative is either theoretical or relies heavily on one dimension thereof, namely corruption. The phenomenon is not dealt with in the context of state-building, state theory or as a feature of liberationism under conditions of a liberal democratic experiment.

The African National Congress (ANC), as a liberation movement managing the state in a liberal democratic constitutional democracy, is often described as a neo-patrimonial state. Significant volumes of research and scholarly papers contributed to the connective tissue between liberationism and neo-patrimonialism. Bogaards (2004), Adams (2009), Darracq (2008), and Lodge (2014) have conducted thorough and substantive theoretical expositions of neo-patrimonialism and its conceptual and operational relations to liberationist theory or one-party dominant states.

Friedman (2014) focuses on class formation in the context of weak states and strong societies (Migdal, 1988), and despite the history of Marxian analytical theory - in the context of developing political economies - class analysis may well be less appreciated than is required by scholars of post-apartheid theory in South Africa. The scope of this article does not allow for a scholarly venture into class theory, but it certainly presents a worthy analytical challenge. Similarly, rational-choice theory (Adams, 1999) could add to the discourse, espe- cially if juxtaposed with theoretical dispositions about state capture as a state-building project in liberal-democratic experiments.

\section{DISCUSSION}

In well-functioning democratic systems, the majority party or coalition of parties manages the affairs of the state. Party officials appointed to the state serve the purpose of designing policy regimes, which will embed the party's manifesto and election promises. While such policy regimes are aimed at the electoral support of the governing party, it has to serve the collective interests of civil society. The assumption is that, especially in homogeneous political economies, even the supporters of the governing party would prefer that policies serve a set of interests beyond the realm of sectarian interests (Schorske, 1998, p. 56). In deeply divided societies - more so if those divisions are historical and marred by contending moral justifications for distribution or redistribution - the likeliness of the supporters of the majority party exhibiting compassion beyond the 'in-group' diminishes to varying degrees. Under such conditions, the dominating political elite is tempted to occupy the state, rather than managing it; and it often has the sanction of its electoral support to contest the rights of 'out-groups' to the universal privileges of constitutionalism (Hellman, Jones, Kaufmann, \& Schankerman, 2000, p. 80).

State capture not only subverts the distributive regulations of the state, it also permeates and corrodes the constitutionally embedded values of equality, justice and social trust. The operational distance between the spheres of the state is a constitutionally prescribed systemic separation of powers, but this separation - equally so - is entrenched between the operational realm of the state and that of society (Grzymala-Busse, 2008, p. 38). The democratic space between state and society is traversed only by a complex set of social and juristic relations, which manages the conflict and regulates the extractive and distributive obligations and responsibilities of the state.

The propensity of the state to encroach on the operational realm of civil society is monitored not only by the judiciary but also by a plethora of institu- 
tions such as non-governmental organizations, as well as international non-governmental aggregates. The statutory architecture of the relational tissue between state and society could be legitimized by a justifiable interventionist regime aimed at correcting structural injustices or a regulatory regime, which gives the society the sufficient autonomy to largely manage its own affairs. However, in a democratic, constitutional dispensation, it is assumed that when the state changes the nature of its relationship with society - for instance from regulatory to interventionist - such changes come about as a consequence of either a newly negotiated consensus or a compromise with the societal aggregates representing the 'greater good.'

The question is, how does a polity reclaim the domain of the constitutional democracy once state-societal relations have been fractured by successful attempts by opportunistic or corrupt actors within the economy to 'capture' the state's extractive and distributive regimes. The 'push back' is multivariate. State capture engineers are operative at all three spheres of the South African state, as well as within the statutory institutions of state control and mediation such as the National Prosecuting Authority (NPA), the Directorate of Priority Crime Investigation (DPCI), also known as the Hawks, and the South African Police Service (SAPS). It is also investigated for its presence in the extractive regime, which includes the South African Revenue Service (SARS), the national treasury, and the (re)distributive regimes such as the various tender boards operative in state-owned corporations, as well as the national, provincial and local bureaucracies of the state.

The independence of whoever is appointed to lead these institutions is of utmost importance to serve the society in the interest of the greater good. Almost all of these institutions had been implicated over the past two decades of being captured by opportunistic interests beyond the constitutional realm of the state (Mbeki, 2005, p. 33). In terms of the constitution, the president of the Republic of South Africa is responsible for the final approval and/or appointment of office bearers to lead these institutions of social order and control. If the president manages the state in a manner, which benefits or encourages opportunistic interests in the private economy preferential access not only to the resources of the state, but also the policy agenda and distributive regime of the state, it is possible to capture a large number of institutional arrangements for serving sectarian, opportunistic or corrupt interests (Mathekga, 2016, p. 134). The point also made by Schorske $(1998$, p. 33$)$ is that it may well be possible to not only gain access to the largesse of the state distributive regime, but also capture the policy agenda of (re)distribution, and then redirect the flow of capital and goods to services away from the greater good.

If society, the media, the judicial system, and the electorate revolt against the captured regime or the president as the head of government, it is possible to repulse the institutionalization of state capture by removing the president of the republic. However, in post-conflict polities such as South Africa, with the liberation regime usurping the state rather than managing it for the greater good, the connective tissue between the party and the state is inevitably embedded in the institutional and statutory arrangements of empowerment and redress, which provides the moral justifications for sectarianism (Grzymala-Busse, 2008, p. 76). Cadre deployment refers to the governing party employing its members to legitimize a particular regime benefiting the ruling party, thereby consolidating its right to control rather than to manage.

Thus, following on the argument of Mbeki (2005, pp. 67-69), to liberate the state from sectarian interests that have captured the managerial regime of the state, regime change will have to occur in the governing party first. If the benefits of state capture have permeated the governing party to the extent that it defines most or all social, political and economic relations within the party, it may well be impossible for the operative features of the party to revert to the dictates of the constitutional state. However, since state capture relies heavily on limiting access to the benefits of the captured state or resources, the governing party is more likely to be divided between insiders and outsiders. For outsiders recapturing the governing party it becomes an important impulse, as exclusion from the captured regime also diminishes the political authority of those excluded from the distributive and redistributive regime of the party, as well as that of the state, where lists party are compiled in regions and districts. 


\section{CONCLUSION}

State capture as a feature of state-societal relations - or even as a process or method of institutionalization of a contending variant of social order in liberal democratic experiments - affords political theorists with another opportunity to rethink key concepts defining the connective tissue between the state, society and the economy. It is important the distinguish state capture from the notion of the parallel state, systemic corruption, weak state and fragmented societies, patrimonialism, or patron-clientelism.

Perhaps the most important attribute of a theoretical review is the reassessment of the conceptual confines of the theory. Case studies often determine the conceptual content of theory, and theory is the outcome of contending narratives. Comparative analysis and the scientific method allow for a large complexity of case studies to be assessed by applying a 'unified' theory; such a theory, however, is subject to revision due to varying and changing social, political and economic conditions.

The theoretical review of this article might well be specific to South Africa as a case study, but it could also be used as a frame of reference to case studies in Southern Africa and of developing political economies. It certainly has a broader interpretative application in developing the political economies. By October 2019, various commissions were still investigating the real width and depth of state capture in South Africa. Based on the finding of these commissions and the prosecutions to follow, the conceptual confines and operational architecture of state capture theory will evolve, and provide scholarly interests with a complexity of research questions to ponder.

\section{REFERENCES}

1. Adams, J. (1999). Culture in Rational-Choice Theories of State-Formation. In George Steinmetz (Ed.), State/Culture: State-Formation after the Cultural Turn (pp. 98-122). Ithaca, New York: Cornell University Press. Retrieved from https://sociology. yale.edu/publications/culturerational-choice-theories-stateformation

2. Adams, J. (2009). The Rule of the Father: Patriarchy and Patrimonialism in Early Modern Europe. Retrieved from https:// www.russellsage.org/sites/all/files/ u4/Adams_Rule $\% 20$ of\%20the $\% 20$ Father.pdf

3. Basson, A., \& Du Toit, P. (2017). Enemy of the State. Cape Town: Jonathan Ball Publishers.

4. Beresford, A. (2009). Comrades back on track: the durability of the Tripartite Alliance. African Affairs, 108(432), 391-412. Retrieved from https://doi.org/10.1093/afraf/ adp021

5. Bogaards, M. (2004). Counting parties and identifying dominant party systems in Africa. European Journal of Political Research, 173-197. https://doi.org/10.1111/ j.1475-6765.2004.00150.x

6. Darracq, V. (2008). The ANC's organization at the grassroots. African Affairs, 107, 589-609. Retrieved from https://www.jstor. org/stable/27667071?seq=1\#page_ scan_tab_contents

7. Erdmann, G., \& Engel, U. (2007). Neopatrimonialism reconsidered: critical review and elaboration of an elusive concept. Commonwealth and Comparative Politics, 45(1), 95-119. https://doi. org/10.1080/14662040601135813

8. Friedman, S. (2014). South Africa's Real Ticking Time Bomb: The Black Middle Class. Retrieved from https://sacsis.org.za/site/ article/2024 (accessed on January 21, 2019).

9. Global Initiative against Transnational Organized Crime (GITOC). Report. Retrieved from https:// www.uct.ac.za/sites/default/files/ image_tool/images/328/media/ releases/2018/2018-03-20_Release.
ContractKillings.pdf $\% 202018 \% 20$ 2018

10. Government Gazette (1996). The Constitution of the Republic of South Africa, 1996 (Section 217 in specific reference). Retrieved from https://www.gov.za/sites/default/ files/gcis_document/201409/act1080f1996s.pdf

11. Grzymala-Busse, A. (2008). Beyond Clientelism: Incumbent State Capture and State Formations. Comparative Political Studies, 41(4), 38-73. https://doi.org /10.1177\%2F0010414007313118

12. Hellman, J. S., Jones, G., Kaufmann, D., \& Schankerman, M. (2000). Measuring Governance, Corruption and State Capture: How Firms and Bureaucrats Shape the Business Environment in Transition Economics (Policy Research Working Papers No 2312). The World Bank. Washington DC. Retrieved from http://documents.worldbank.org/ curated/en/241911468765617541/ Measuring-governance-corruption-and-State-capture-how- 
firms-and-bureaucrats-shape-thebusiness-environment-in-transition-economies

13. ICLG (International Comparative Legal Studies) (2018). Retrieved from https://iclg.com/practiceareas

14. Kreps, D. M. (1990). Corporate Culture and Economic Theory. In Perspectives on Positive Political Economy (pp. 90-142). New York, NY: Cambridge University Press. Retrieved from https://www.gsb. stanford.edu/faculty-research/ publications/corporate-cultureeconomic-theory

15. Lodge, T. (2014). Neo-patrimonial politics in the ANC. African Affairs, 113(450), 1-23. Retrieved from https://doi.org/10.1093/afraf/ adt069

16. Mathekga, R. (2016). When Zuma Goes. Cape Town: NB Publishers. Retrieved from https://www. amazon.com/When-Zuma-RalphMathekga-author/dp/0624080676

17. Mbeki, M. (2005). Perpetuating Poverty in Sub-Saharan Africa: How African Political Elites Undermine Entrepreneurship and Economic Development (International Policy Network).
London. Retrieved from https:// gsdrc.org/document-library/perpetuating-poverty-in-sub-saharan-africa-how-african-politicalelites-undermine-entrepreneurship-and-economic-development/

18. Migdal, J. S. (1988). Strong Societies and Weak States: State-Society Relations and State Capabilities in the Third World. New York: Princeton University Press. Retrieved from https:// press.princeton.edu/books/paperback/9780691010731/strongsocieties-and-weak-states

19. Pauw, J. (2017). The President's Keepers. Cape Town: NB Publishers. Retrieved from https:// www.amazon.com/PresidentsKeepers-Those-keeping-prisonebook/dp/B076YBL1WS

20. Pipes, R., \& Koenker, D. P. (1993). The Russian Revolution. The Journal of Modern History, 432-435. Chicago: University of Chicago Press.

21. Pitcher, A., Moran, M., \& Johnston, M. (2009) Rethinking Patrimonialism and Neopatrimonialism in Africa. African Studies Review, 52(1), 125-156. https://doi.org/10.1353/ arw.0.0163
22. Quimpo, N. G. (2005). Oligarchic Patrimonialism, Bossism, Electoral Clientelism and Contested Democracy in the Philippines. Asian Studies Review, 23(3), 33-66.

23. Schorske, C. E. (1998). Thinking with History: Explorations in the Passage to Modernism. Princeton, New Jersey: Princeton University Press. Retrieved from https://www. amazon.com/Thinking-HistoryExplorations-Modernism-Princeton/dp/0691635382

24. Subudubudu, D. , \& Molutsi, P. (2009). Politics, Leadership and Coalitions in Development. In A. Leftwich \& C. A. Wheeler, Research and Policy Workshop Report. 2011. Retrieved from https://www.scribd.com/ document/224783071/PoliticsLeadership-and-Coalitions-inDevelopment-Findings-Insightsand-Guidance

25. World Bank (n.d.). World Bank Report (2014-2017). Retrieved from https://www.worldbank.org/ en/country/southafrica/overview.

26. World Bank Group Report. (2016). Political Economy. Retrieved from https://elibrary.worldbank.org/ doi/abs/10.1596/9780821387856 $\mathrm{CH} 08$ 